\title{
Industrial and environmental applications of white-rot fungi
}

\author{
Rodríguez-Couto $S^{1,2}$
}

${ }^{1}$ Ceit-IK4, Water \& Health Division, 20018 Donostia-San Sebastian, Spain, srodriguez@ceit.es

${ }^{2}$ IKERBASQUE, Basque Foundation for Research, María Diaz de Haro 3, 48013, Bilbao, Spain

Rodríguez-Couto S. 2017 - Industrial an environmental applications of white-rot fungi. Mycosphere 8(3) 456-466, Doi 10.5943/mycosphere/8/3/7

\begin{abstract}
White-rot-fungi (WRF) are the only organisms able to degrade the whole wood components (i.e. lignin, cellulose and hemicellulose). This ability is due to the secretion of extracellular nonspecific ligninolytic enzymes during their secondary metabolism usually triggered by nutrient exhaustion. The non-specificity of these enzymes enables them to transform a great variety of recalcitrant and hazardous pollutants such as polycyclic aromatic hydrocarbons (PAHs), pesticides, fuels, alkanes, polychlorinated biphenyls (PCBs), explosives and synthetic dyes. In addition, their extracellular nature allows WRF to access non-polar and insoluble compounds. This makes WRF very appealing for their application to different industrial and biotechnological processes. Also, new potential commercial products and processes from the fungal treatment of lignocellulosic materials may arise. The implementation of such applications would contribute to the establishment of a more sustainable industry and the development of a circular economy.
\end{abstract}

Key words - biotechnology - degradation - lignin - ligninolytic enzymes - valorisation

\section{Introduction}

White-rot fungi (WRF), so-named because of the whitish colour of the delignified wood, are the only known organisms able to mineralise the recalcitrant and bulky heteropolymer lignin (Figure 1). This ability is due to the secretion of extracellular non-specific enzymatic complexes during their secondary metabolism (Wesenberg et al. 2003), usually under limited nutrient availability ( $\mathrm{C}: \mathrm{N}$ ratio) with nitrogen being the limiting nutrient for fungal growth in most wood and soils (Kirk \& Farrell 1987). These enzymatic complexes mainly consist of lignin peroxidases (LiPs, EC 1.11.1.14), manganese-dependent peroxidases (MnPs, EC 1.11.1.13) and laccases (benzenediol:oxygen oxidoreductases, EC 1.10.3.2) together with accessory enzymes (Ruiz-Dueñas \& Martínez 2009). The non-specificity of these enzymes enables them to transform a great variety of persistent chemicals with a structure similar to lignin (Mansur et al. 2003). Furthermore, their extracellular nature allows the fungi to access non-polar and insoluble compounds (Levin et al. 2003). This makes WRF very attractive for different industrial and biotechnological applications such as the production of biofuel from plant biomass, biopulping, biobleaching and the degradation of recalcitrant environmental pollutants.

WRF are ubiquitous in nature, particularly in hardwood forests as hardwood (e.g. birch and aspen) is more susceptible to the attack of WRF than softwood (e.g. spruce and pine) (Blanchette et al. 1990). WRF can degrade all wood components (i.e. cellulose, hemicellulose and lignin) or preferentially lignin. The former are named simultaneous or non-selective WRF and the latter 
selective WRF. The selective WRF are of special bioindustrial interest, since they remove lignin leaving the valuable cellulose intact (Dashtban et al. 2010). There are also WRF that cause both types of white-rot attack within one substrate (Blanchette 1984, Blanchette et al. 1985, Adaskaveg \& Gilbertson 1986).

The mechanisms on how WRF degrade lignin are not fully understood but the fungal strain, the origin of lignocellulose and the culture conditions play a major role in the process (van Kuijk et al. 2015). Also, individual fungi can considerably vary their ability to degrade specific substrates under the same environmental conditions (Eriksson et al. 1990).

\section{Potential applications of white-rot fungi}

\section{Bioremediation of environmental pollutants}

One of the main environmental problems facing the world nowadays is the pollution of soil, water and air by toxic chemicals. Most of these chemicals are known to be carcinogenic and mutagenic posing a serious hazard to the ecosystem and human beings. Therefore such compounds have to be removed before entering into the environment. However, the in-use techniques for the treatment of these type of compounds are rather costly, time-consuming, mostly ineffective and sometimes generate hazardous sub-products (Grassi et al. 2011). Consequently, alternative methods to remove these hazardous recalcitrant compounds are needed. In this sense, the use of WRF represents a promising approach.

Due to the similarity between the chemical structure of lignin and those of many recalcitrant pollutants, such as polycyclic aromatic hydrocarbons (PAHs), pesticides, fuels, alkanes, polychlorinated biphenyls (PCBs), explosives and synthetic dyes (Figure 2), the use of WRF for the degradation of such pollutants has been considered (Paszczynski et al. 1991). This feature is the greatest advantage of using WRF in bioremediation, since a mixture of different pollutants is usually found in most polluted sites (Mester \& Tien 2000). Also, WRF can bear a broad range of environmental conditions and, in addition to this, they can use lignocellulose for growth making them suitable for inoculation into polluted soils. Moreover, WRF can exert a positive effect on the growth of the indigenous micro-organisms facilitating the degradation of recalcitrant pollutants.

The first studies on pollutant degradation by WRF were performed with the white-rot fungus Phanerochaete chrysosporium (Figure 3A), which has become the model organism for lignin degradation studies (Bumpus et al. 1985). Since them, other species of WRF with promising ability to degrade recalcitrant pollutants have been described, including species belonging to the genera Pleurotus, Bjerkandera, Coriolopsis, Phlebia and Trametes (Rodríguez et al. 2004). In particular, the non-selective white-rot-fungus Trametes versicolor (Figure 3B) has been repeatedly used in assays as a WRF representative (Blanchette \& Burnes 1988).

The biotransformation of pollutants by WRF entails different processes started either by the ligninolytic enzymes or the mycelial-bound redox system that produce free radicals, which can then perform either another enzyme-catalysed oxidation or non-enzymatic transformations via enzyme combustion. However until whole pollutant mineralisation, the use of different toxicity tests are needed to ensure the safety of the by-products formed (Jurado et al. 2011).

The ability of WRF to remove recalcitrant pollutants from wastewater has shown to be a good alternative to traditional wastewater treatment technologies. In addition, WRF have shown promising potential for the bioremediation of industrially-contaminated soils (Borràs et al. 2010; Anasonye et al. 2015). However, nowadays bioremediation on a commercial scale uses prokaryotes with comparatively few recent attempts to use WRF despite their clear advantages for bioremediation over bacteria (Table 1). In addition, WRF treatments would expand the substrate range of current treatments by degrading pollutants that prokaryotes cannot (Pointing 2001). Nevertheless, the use of WRF in bioremediation presents the following drawbacks: long growth cycle, requiring nitrogen limiting conditions, long hydraulic retention time (Banat et al. 1996, Saratale et al. 2009) and low pH for optimum enzyme activity (Doble \& Kumar 2005) which make the maintenance of WRF in bioreactors problematic. Additionally, several operational problems, 
such as formation of mycelia aggregates, electrode fouling and clogging, can made necessary the removal of fungal biomass from the bioreactors after short operation periods (Karthikeyan \& Sahu 2014). Also, despite different authors have reported the potential of WRF to treat industrial wastewater, there are few studies at bioreactor scale operating in continuous mode and under nonsterilised conditions. Therefore, the application of WRF at industrial scale remains as a technical challenge.

\section{Pulp and paper industry}

During pulp and paper production, it is necessary to separate the cellulose fibres from lignin. This is performed by using mechanical or chemical methods. In chemical pulping, lignin is solubilised by chemicals resulting in a brown residual material that must be removed to produce white paper. For this, elemental chlorine has been used for a long time but currently delignification with oxygen and hydrogen peroxide is being used. However, they are less efficient in achieving a high degree of brightness than the chlorine reagents.

The treatment of wood chips with ligninolytic fungi prior to conventional pulping methods (mechanical, chemical or a combination of both) is named biopulping. WRF have been considered as potentially useful agents for biopulping because they reduce not only energy consumption but also chemicals, thus, being environmentally-friendly in contrast with the conventional pulping. In addition, biopulping not only removes lignin but also some of the wood extractives, thereby reducing the pitch content and effluent toxicity (Ali \& Sreekrishnan 2001).

The biological delignification of wood by WRF was first considered by Lawson \& Still (1957) at the West Virginia Pulp and Paper Company Research Laboratory (now Westvaco Corp.) (Akhtar et al. 1998). Since then, many researchers have studied the potential use of WRF in pulping processes and pilot mill trials have been started in the last decades (Farrell et al. 1997, Breen \& Singleton 1999, Scott et al. 2002, Masarin et al. 2009). The efficiency of fungal pre-treatment utilising different lignocellulosic materials has been described and several patents have been published, the one based on the use of Ceriporiopsis subvermispora being the most optimised one (Gutiérrez et al. 2001). This species has also proven to be very competitive on both softwoods and hardwoods (Ferraz et al. 2007).

The pre-treatment of wood chips by WRF has shown to improve the effectiveness of kraft pulping and paper brightness (Fonseca et al. 2014). Therefore it can be considered as a possible alternative to chemical pulping since, in addition to this, it requires simpler equipment and produces an effluent with reduced BOD.

\section{Valorization of lignocellulosic wastes}

The accumulation of huge amounts of lignocellulosic wastes from human activity is considered a serious environmental problem (Dias et al. 2010). The major constituent of lignocellulosic materials is cellulose followed by hemicellulose and lignin (Figure 4). Cellulose and hemicellulose are macromolecules built from different sugars, whereas lignin is an aromatic polymer synthesised from phenylpropanoid precursors. The composition and proportions of these components vary between plants (Sánchez et al. 2009). Lignin degradation by using chemical and physical methods is a process neither environmentally-friendly nor economical. The use of WRF is being considered as an attractive alternative to transform these wastes into value-added products.

\section{Production of relevant metabolites}

Different lignocellulosic wastes have been used as support-substrates for the production of different metabolites of industrial or commercial interest by WRF, generally under solid-state fermentation (SSF) conditions. The use of such wastes not only reduces considerably de production costs but also helps to alleviate the economic and the environmental problems caused by their disposal. Although most of the produced metabolites are ligninolytic enzymes (Rodríguez-Couto \& Sanromán 2005) other value-added products such as organic acids are also obtained (Table 2). In addition, recently the application of bioactive compounds produced by WRF to the food and 
pharmaceutical industry has impelled the search for novel bioactive compounds of fungal origin (Wong et al. 2010). Moreover, their production has become an important field in modern biotechnology. Thus, the white-rot-fungus Ganoderma lucidum has been reported to produce several bioactive compounds with high therapeutic value (Paterson 2006). Also, recently the whiterot fungus Cerrena unicolor has shown to exhibit antiviral, immunomodulatory and anticancer activities (Mizerska-Dudka et al. 2015).

\section{Bioethanol}

Biofuel production from renewable sources has received increased interest in recent years as an alternative to the use of fossil fuels in many countries. Lignocellulosic biomass, mostly from agricultural and forestry wastes, is rich in carbohydrates and widely available, thus, providing attractive feedstocks for ethanol production. To maximise the use of carbohydrates from the biomass a pre-treatment process is required. The current in use technologies are costly hampering the commercialisation of bioethanol (Mosier et al. 2005). This has impelled the search for alternative processes such as those based on WRF. Thus, several WRF, such as Phanerochaete chrysosporium, Pleurotus ostreatus, Trametes versicolor, Cyathus stercoreus and Ceriporiopsis subvermispora, have been studied for the pretreatment of different lignocellulosic wastes (Wan \& Li 2012; Knežević et al. 2013). However, despite that the use of WRF offers the following advantages over the current thermal or chemical pre-treament processes: simpler techniques, low energy requirements, no or reduced waste streams, reduced downstream processing costs and no or reduced inhibitors to ethanol fermentation (Keller et al. 2003; Nigam \& Pandey 2009), substantial holocellulose (cellulose and hemicellulose) loss and long pre-treatment times are the main drawbacks of this process. So to ensure a cellulose-rich but highly delignified biomass for biofuel production, highly selective lignin degraders are preferred.

\section{Ruminant feed}

Cellulose and hemicellulose in most lignocellulosic wastes are highly linked to lignin which makes them difficult to digest by animals (Arora \& Sharma 2009). This hampers the use of such wastes by rumen microbes and currently chemical and/or physical treatments are used to degrade lignin (Chaturvedi \& Verma 2013). In search for alternative treatments to the use of chemicals or expensive physical treatments, the use of WRF is seen as a very attractive alternative. In particular to convert lignocellulosic wastes into ruminant feeding, selective lignin degraders are the preferred WRF since they left cellulose intact and, thereby, keep the energy value of such wastes. However, only small laboratory scale experiments involving singles substrates or fungal species have been conducted so far. Further optimisation is needed to develop an alternative treatment able to compete with the conventional treatments (van Kuijk et al. 2015).

\section{Outlook}

The practical use of WRF for biotechnological applications holds great potential. However before this can become a reality, progress related to process optimisation and cost reduction is needed. Searching for novel micro-organisms, taking advantage of the enormous microbial diversity existing in aquatic and terrestrial environments, is also required. The ocean is an enormous reservoir of untapped micro-organisms.

The advantages and disadvantages of using WRF or their enzymes in biotechnological applications should be evaluated before attempting industrial-scale operations. In comparison to fungal biomass, enzymes are still more expensive to produce at an industrial scale in spite of their potential for scaling up through gene technologies. However with the increasing advances in enzyme immobilisation technologies, efficiency in enzyme reusing both in amount and activity is probably to be greater than that of fungal biomass. 
Table 1 Advantages of using white-rot-fungi (WRF) over bacteria for bioremediation (Maloney 2001).
(i) They use inexpensive and easily available lignocellulosic materials as a nutrient source
(ii) They can tolerate relatively high concentrations of pollutants due to their extracellular degradation system
(iii) They are able to survive in the presence of several xenobiotics that may be toxic to other microorganisms
(iv) They are able to degrade a mixture of chemicals thanks to their non-specific free-radical-based degradation mechanism
(v) They do not need pre-conditioning to a particular pollutant
(vi) They can tolerate a wide range of environmental conditions
(vii) The rate of degradation or biotransformation of a pollutant is proportional to its concentration and, so, the solubility of the pollutant is not important

Table 2 Examples of different value-added metabolites produced by white-rot fungi grown on lignocellulosic wastes under solid-state fermentation conditions.

\begin{tabular}{|c|c|c|c|}
\hline White-rot fungus & $\begin{array}{l}\text { Lignocellulosic } \\
\text { waste }\end{array}$ & Product(s) & Reference \\
\hline Fomes fomentarius & $\begin{array}{l}\text { Granary waste (small } \\
\text { grains, husks and } \\
\text { straw, and straw of } \\
\text { barley, oats, rye and } \\
\text { wheat) }\end{array}$ & Crude protein & Hatakka \& Pirhonen 1985 \\
\hline $\begin{array}{l}\text { Nematoloma } \\
\text { frowardii }\end{array}$ & Wheat straw & $\begin{array}{l}\text { Manganese peroxidase, } \\
\text { organic acids }\end{array}$ & Hofrichter et al. 1999 \\
\hline $\begin{array}{l}\text { Phanerochaete } \\
\text { chrysosporium, } \\
\text { Phlebia radiata }\end{array}$ & Corncob & Protease & Cabaleiro et al. 2002 \\
\hline $\begin{array}{l}\text { Dichomitus squalens, } \\
\text { Phanerochaete } \\
\text { sanguinea, Trametes } \\
\text { ochracea, Trametes } \\
\text { versicolor }\end{array}$ & Spruce wood chips & Oxalic acid & Mäkelä et al. 2002 \\
\hline $\begin{array}{l}\text { Physisporinus } \\
\text { rivulosus }\end{array}$ & Spruce wood chips & $\begin{array}{l}\text { Manganese peroxidase, } \\
\text { laccase, oxalic acid }\end{array}$ & Hakala et al. 2005 \\
\hline $\begin{array}{l}\text { Ceriporiopsis } \\
\text { subvermispora }\end{array}$ & $\begin{array}{l}\text { Pinus taeda wood } \\
\text { chips }\end{array}$ & Xylanase & Milagres et al. 2005 \\
\hline Trametes hirsuta & Grape seeds & Laccase & Rodríguez-Couto et al. 2006 \\
\hline $\begin{array}{l}\text { Bjerkandera adusta, } \\
\text { Pycnoporus } \\
\text { sanguineus }\end{array}$ & $\begin{array}{l}\text { Oak and cedar } \\
\text { sawdust, rice husk, } \\
\text { corn stubble, wheat } \\
\text { straw, Jatropha seed } \\
\text { husk }\end{array}$ & Cellulase, xylanase & Quiroz-Castañeda et al. 2011 \\
\hline Cerrena unicolor & Oat husks & $\begin{array}{l}\text { Manganese peroxidase, } \\
\text { laccase }\end{array}$ & Moilanen et al. 2015 \\
\hline Coriolopsis gallica & Sawdust waste & Laccases & Daâssi et al. 2016 \\
\hline
\end{tabular}




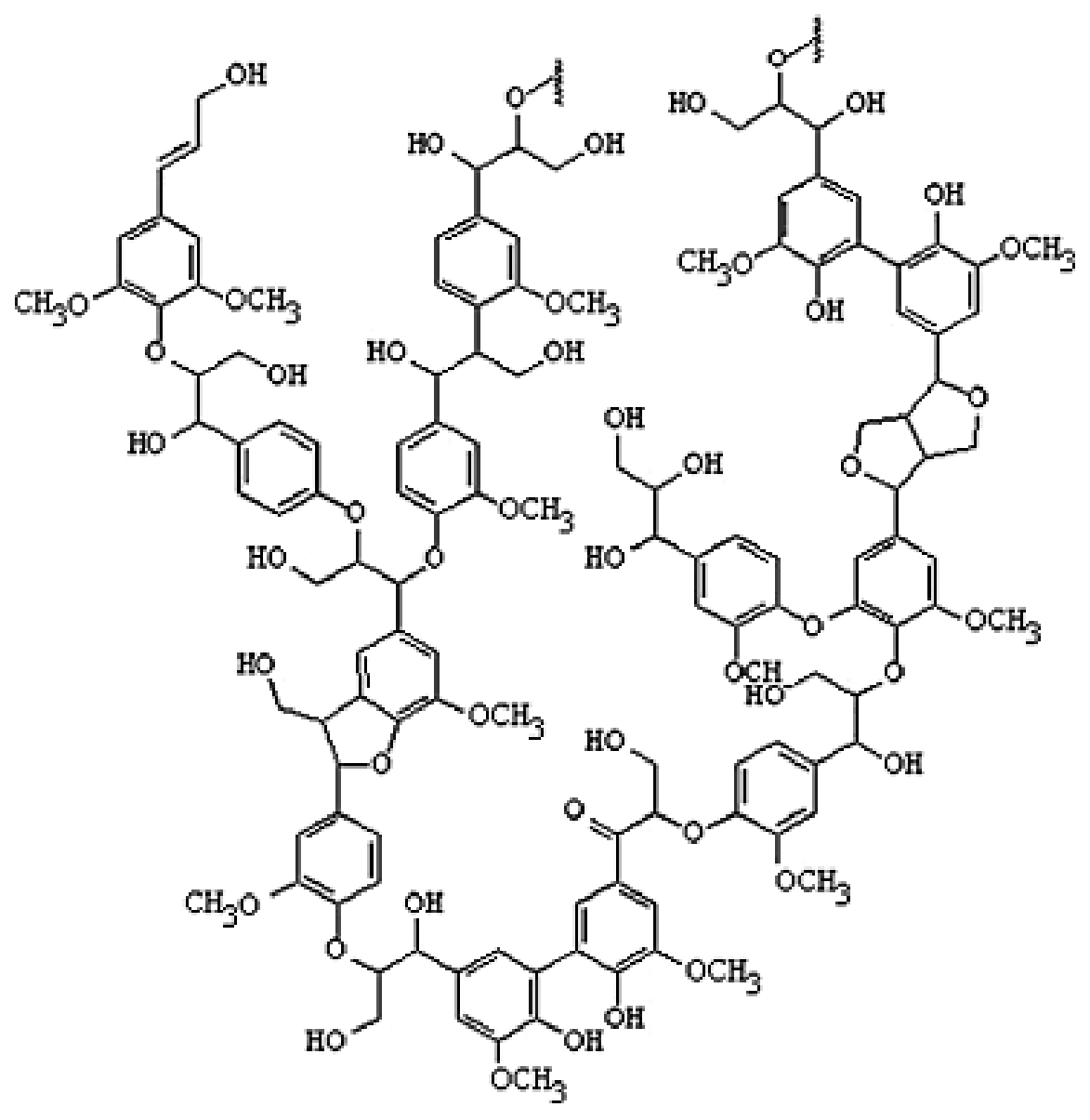

Fig. 1 - Schematic structure of a lignin molecule (source: www.research.uky.edu/.../green energy.html).<smiles>CCOP(=S)(OCC)Oc1nc(Cl)c(Cl)cc1Cl</smiles>

Chlorpyrifos<smiles>CC(C)(c1ccc(O)cc1)c1ccc(O)cc1</smiles>

Bisphenol A<smiles>CC(=O)Nc1ccc2cc(S(=O)(=O)O)c(N=Nc3ccc(S(=O)(=O)CCOS(=O)(=O)O)cc3)c(O)c2c1</smiles>

Reactive Orange 16<smiles>Cc1c([N+](=O)[O-])cc([N+](=O)[O-])cc1[N+](=O)[O-]</smiles>

2, 4, 6-trinitrotoluene

Fig. 2 - Different environmental pollutants degraded by the white-rot-fungi. 


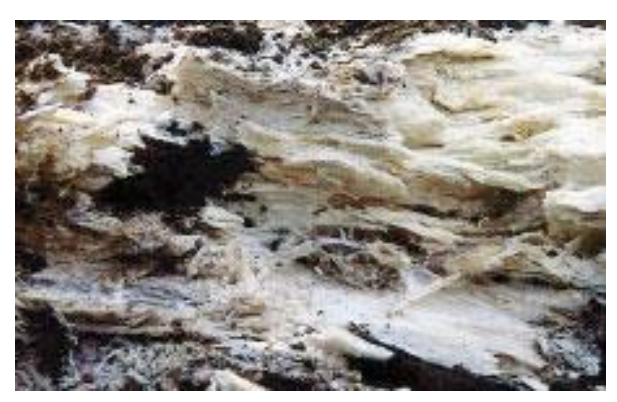

A

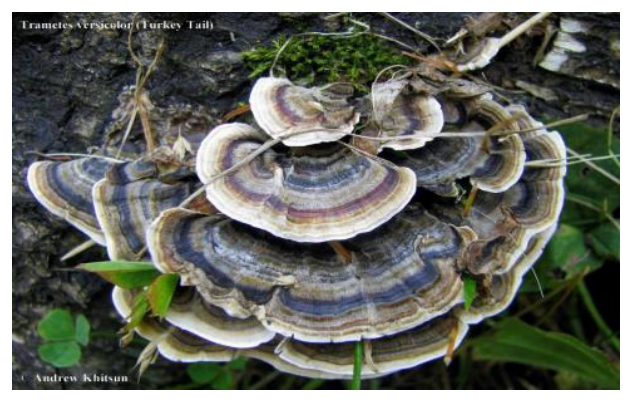

B

Fig. 3 - Pictures of the white-rot fungi Phanerochaete chrysosporium (A; source https://microbewiki.kenyon.edu/) and Trametes versicolor (B; source http://www.wisconsinmushrooms.com/) as grown in nature.

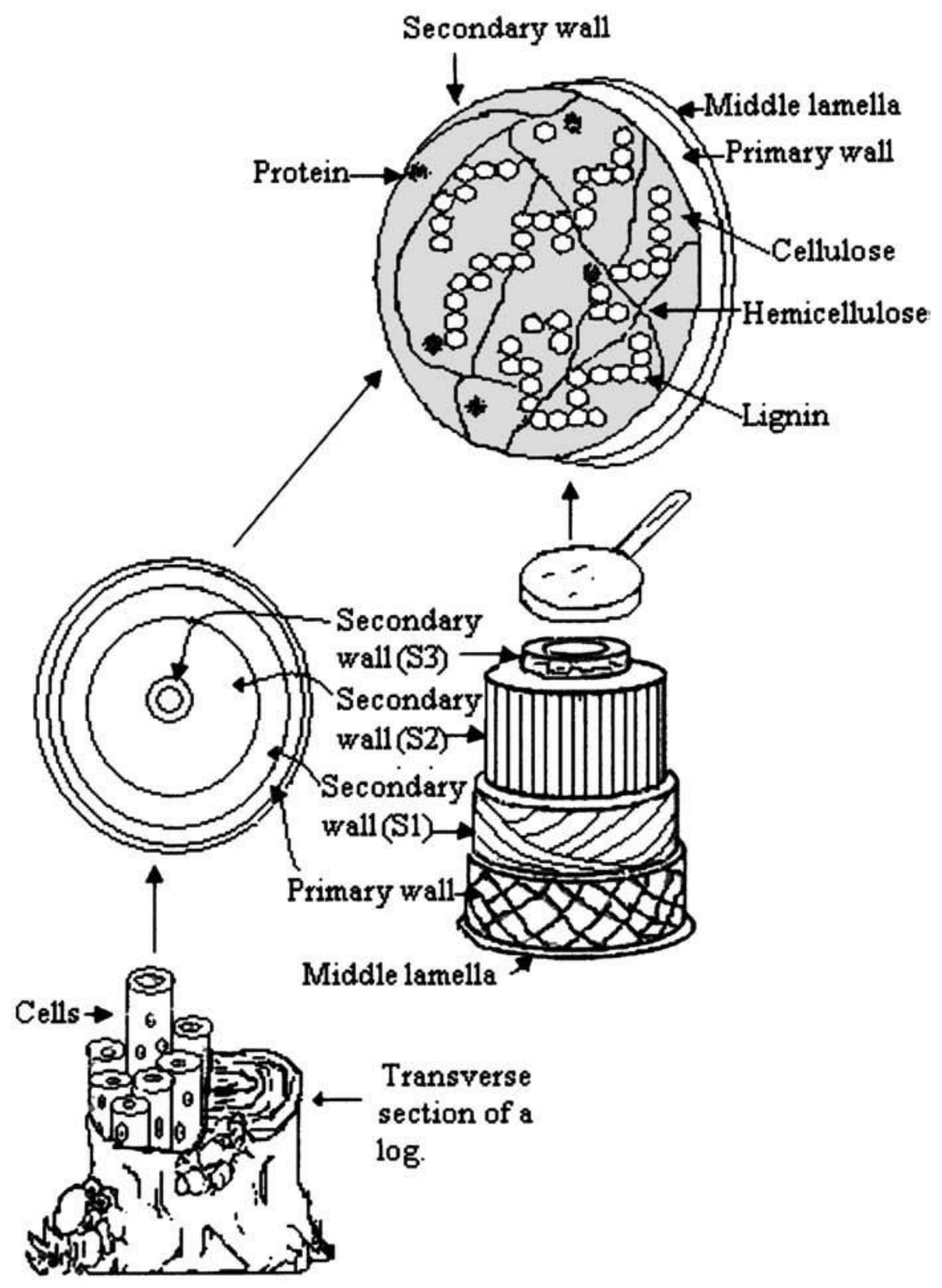

Fig. 4 - Major components of wood. 


\section{References}

Adaskaveg JE, Gilbertson RL. 1986 - In vitro decay studies of selective delignification and simultaneous decay by the white rot fungi Ganoderma lucidum and Ganoderma tsugae. Canadian Journal of Botany 64, 1615-1629.

Akhtar M, Blanchette RA, Myers GC, Kirk TK. 1998 - An overview of biochemical pulping research. In: Young RA and Akhtar M (eds.). Environmentally friendly technologies for the pulp and paper industry. Wiley New York, 309-419.

Ali M, Sreekrishnan TR. 2001 - Aquatic toxicity from pulp and paper mill effluents: A review. Advances in Environmental Research 5, 175-196.

Anasonye F, Winquist E, Räsänen M, Kontro J, Björklöf K, Vasilyeva G, Jorgensem KS, Steffen, KT, Tuomela M. 2015 - Bioremediation of TNT contaminated soil with fungi under laboratory and pilot scale conditions. International Biodeterioration \& Biodegradation 105, 712.

Arora DS, Sharma RK. 2009 - Enhancement in in vitro digestibility of wheat straw obtained from different geographical regions during solid state fermentation by white rot fungi. Bioresources 4, 909-920.

Banat IM, Nigam P, Singh D, Marchant R. 1996 - Microbial decolourization of textile dyes containing effluents: a review. Bioresource Technology 58, 217-227.

Blanchette RA, Burnes TA. 1988 - Selection of white-rot fungi for biopulping. Biomass 15, 93101.

Blanchette RA, Nilsson T, Daniel GF, Abad AR. 1990 - Biological degradation of wood. In: Rowell RM and Barbour J (eds.). Archaeological wood: properties, chemistry and preservation. American Chemical Society Washington DC, 147-174.

Blanchette RA, Otjen L, Effland MJ, Eslyn WE. 1985 - Changes in structural and chemical components of wood delignified by fungi. Wood Science and Technology 1, 35-46.

Blanchette RA. 1984 - Manganese accumulation in wood decayed by white rot fungi. Phytopathology 74, 153-160.

Borràs E, Caminal G, Sarrà M, Novotny C. 2010 - Effect of soil bacteria on the ability of polycyclicaromatic hydrocarbons (PAHs) removal by Trametes versicolor and Irpex lacteus from contaminated soil. Soil Biology and Biochemistry 42, 2087-2093.

Breen A, Singleton FL. 1999 - Fungi in lignocellulose breakdown and biopulping. Current Opinions in Biotechnology 10, 252-258.

Bumpus JA, Tien M, Wright D, Aust SD. 1985 - Oxidation of persistent environmental pollutants by a white rot fungus. Science 228, 1434-1436.

Cabaleiro DR, Rodríguez-Couto S, Sanromán A, Longo MA. 2002 - Comparison between the protease production ability of ligninolytic fungi cultivated in solid state media. Process Biochemistry 37, 1017-1023.

Chaturvedi V, Verma P. 2013 - An overview of key pretreatment processes employed for bioconversion of lignocellulosic biomass into biofuels and value added products. Biotechnology 3, 415-431.

Daâssi D, Zouari-Mechichi H, Frikha F, Rodríguez-Couto S, Nasri M, Mechichi T. 2016 - Sawdust waste as a low-cost support substrate for laccases production and adsorbent for azo dyes decolorization. Journal of Environmental Health Science \& Engineering 14, 1-12.

Dashtban M, Schraft H, Syed TA, Qin W. 2010 - Fungal biodegradation and enzymatic modification of lignin. International Journal of Biochemistry and Molecular Biology 1, 3650 .

Dias AA, Freitas GS, Marques GSM, Sampaio A, Fraga IS, Rodrigues MAM, Evtuguin DV, Bezerra RM. 2010 - Enzymatic saccharification of biologically pre-treated wheat straw with white-rot fungi. Bioresource Technology 101, 6045-6050.

Doble M, Kumar A. 2005 - Biotreatment of industrial effluents. Elsevier Amsterdam. 
Eriksson KEL, Blanchette RA, Ander P. 1990 - Microbial and enzymatic degradation of wood and wood components. Springer-Verlag Berlin Heidelberg New York.

Farrell RL, Hata K, Wall MB. 1997 - Solving pitch problems in pulp and paper processes by the use of enzymes or fungi. Advances in Biochemical Engineering Biotechnology 57, 197-212.

Ferraz A, Guerra A, Mendonca R, Vicentim MP, Aguiar A, Masarin F, Seabra GG, Pavan PC. 2007 - Mill evaluation of wood chips biotreated on a 50 ton biopulping pilot plant and advances on understanding biopulping mechanisms; 10th International Congress on Biotechnology in the Pulp and Paper Industry. Madison WI.

Fonseca MI, Fariña JI, Castrillo ML, Rodríguez MD, Nuñez CE, Villalba LL, Zapata PD. 2014 Biopulping of wood chips with Phlebia brevispora BAFC 633 reduces lignin content and improves pulp quality. International Biodeterioration \& Biodegradation 90, 29-35.

Grassi E, Scodeller P, Filiel N, Carballo R, Levin L. 2011 - Potential of Trametes trogii culture fluids and its purified laccase for the decolorization of different types of recalcitrant dyes without the addition of redox mediators. International Biodeterioration \& Biodegradation 65, 635-643.

Gutiérrez A, del Río JC, Martínez MJ, Martínez AT. 2001 - The biotechnological control of pitch in paper pulp manufacturing. Trends in Biotechnology 19, 340-348.

Hakala TH, Lundell T, Galkin S, Maijala P, Kalkkinen N, Hatakka A. 2005 - Manganese peroxidases, laccases and oxalic acid from the selective white-rot fungus Physisporinus rivulosus grown on spruce wood chips. Enzyme and Microbial Technology 36, 461-468.

Hatakka AI, Pirhonen TI. 1985 - Cultivation of wood-rotting fungi on agricultural lignocellulosic materials for the production of crude protein. Agricultural Wastes 12, 81-97.

Hofrichter M, Vares T, Kalsi M, Galkin S, Scheibner K, Fritsche W, Hatakka A. 1999 - Production of manganese peroxidase and organic acids and mineralization of ${ }^{14} \mathrm{C}$-labelled lignin $\left({ }^{14} \mathrm{C}\right.$ DHP) during solid-state fermentation of wheat straw with the white rot fungus Nematoloma frowardii. Applied and Environmental Microbiology 65, 1864-1870.

Jurado M, Martínez AT, Martínez MJ, Saparrat MCN. 2011 - Application of white-rot fungi in transformation, detoxification, or revalorization of agriculture wastes: Role of laccase in the processes. Comprehensive Biotechnology 6, 595-603.

Karthikeyan MR, Sahu O. 2014 - Treatment of dye waste water by bioreactor. International Journal of Environmental Bioremediation \& Biodegradation 2, 25-29.

Keller F, Hamilton J, Nguyen Q. 2003 - Microbial pretreatment of biomass. Applied Biochemistry \& Biotechnology 105, 27-41.

Kirk TK, Farrell RL. 1987 - Enzymatic "combustion": the microbial degradation of lignin. Annual Review of Microbiology 41, 465-505.

Knežević A, Ivan M, Mirjana S, Jelena V. 2013 - Potential of Trametes species to degrade lignin. International Biodeterioration \& Biodegradation 85, 52-56.

Kuijk SJA van, Sonnenberg ASM, Baars JJP, Hendriks WH, Cone JW. 2015 - Fungal treated lignocellulosic biomass as ruminant feed ingredient: A review. Biotechnology Advances 33, 191-202.

Lawson Jr LR, Still CN. 1957 - The biological decomposition of lignin: literature survey. Tappi Journal 40, 56A-80A.

Levin L, Viale A, Forchiassin A. 2003 - Degradation of organic pollutants by the white rot basidiomycete Trametes trogii. International Biodeterioration \& Biodegradation 52, 1-5.

Mäkelä M, Galkin S, Hatakka A, Lundell T. 2002 - Production of organic acids and oxalate decarboxylase in lignin-degrading white rot fungi. Enzyme and Microbial Technology 30, 542-549.

Maloney SE. 2001 - Pesticide degradation. In: Gadd GM (ed.). Fungi in bioremediation. University Press Cambridge, 188-223.

Mansur MME, Arias JL, Copa-Patino M, Flärdh, González AE. 2003 - The white-rot fungus Pleurotus ostreatus secretes laccase isozymes with different substrate specificities. Mycologia 95, 1013-1020. 
Masarin F, Pavan PC, Vicentim MP, Souza-Cruz PB, Loguercio C, Ferraz A. 2009 - Laboratory and mill scale evaluation of biopulping of Eucalyptus grandis Hill ex Maiden with Phanerochaete chrysosporium RP-78 under non-aseptic conditions. Holzforschung 63, 259-263.

Mester T, Tien M. 2000 - Oxidation mechanism of ligninolytic enzymes involved in the degradation of environmental pollutants. International Biodeterioration \& Biodegradation 46, 51-59.

Milagres AMF, Magalhaes PO, Ferraz A. 2005 - Purification and properties of a xylanase from Ceriporiopsis subvermispora cultivated on Pinus taeda. FEMS Microbiology Letters 253, 267-272.

Mizerska-Dudka M, Jaszeka M, Błachowicz A, Rejczak TP, Matuszewska A, Osinska-Jaroszuk M, Stefaniuk D, Janusz G, Sulej J, Kandefer-Szerszen M. 2015 - Fungus Cerrena unicolor as an effective source of new antiviral, immunomodulatory, and anticancer compounds. International Journal of Biological Macromolecules 79, 459-468.

Moilanen U, Winquist E, Mattila T, Hatakka A, Eerikäinen T. 2015 - Production of manganese peroxidase and laccase in a solid-state bioreactor and modeling of enzyme production kinetics. Bioprocess \& Biosystems Engineering 38, 57-68.

Mosier N, Wyman C, Dale B, Elander R, Lee YY, Holtzapple M, Ladisch M. 2005 - Features of promising technologies for pretreatment of lignocellulosic biomass. Bioresource Technology 96, 673-686.

Nigam P, Pandey A. 2009 - Solid-state fermentation technology for bioconversion of biomass and agricultural residues. In: Nigam P and Pandey A (eds.). Biotechnology for Agro-Industrial Residues Utilisation. Springer Netherlands, 197-221.

Paszczynski A, Pasti-Grigsby MB, Goszczynski S, Crawford DL, Crawford RL. 1991 - New approach to improve degradation of recalcitrant azo dyes by Streptomyces spp. and Phanerochaete chrysosporium. Enzyme and Microbial Technology 13, 378-384.

Paterson RR. 2006 - Ganoderma - a therapeutic fungal biofactory. Phytochemistry 67, 1985-2001.

Pointing SB. 2001 - Feasibility of bioremediation by white-rot-fungi. Applied Microbiology and Biotechnology 57, 20-33.

Quiroz-Castañeda RE, Perez-Mejia N, Martinez-Anaya C, Acosta-Urdapilleta L, Folch-Mallol J. 2011 - Evaluation of different lignocellulosic substrates for the production of cellulases and xylanases by the basidiomycete fungi Bjerkandera adusta and Pycnoporus sanguineus. Biodegradation 22, 565-572.

Rodríguez E, Nuero O, Guillén F, Martínez AT, Martínez MJ. 2004 - Degradation of phenolic and non-phenolic aromatic pollutants by four Pleurotus species: The role of laccase and versatile peroxidase. Soil Biology and Biochemistry 36, 909-916.

Rodríguez-Couto S, López E, Sanromán MA. 2006 - Utilisation of grape seeds for laccase production in solid-state fermentors. Journal of Food Engineering 74, 263-267.

Rodríguez-Couto S, Sanromán A. 2005 - Application of solid-state fermentation to ligninolytic enzyme production. Biochemical Engineering Journal 2, 211-219.

Ruiz-Dueñas FJ, Martínez AT. 2009 - Microbial degradation of lignin: how a bulky recalcitrant polymer is efficiently recycled in nature and how we can take advantage of this. Microbial Biotechnology 2, 164-177.

Sánchez C. 2009 - Lignocellulosic residues: biodegradation and bioconversion by fungi. Biotechnology Advances 27, 185-194.

Saratale RG, Saratale GD, Kalyani DC, Chang JS, Govindwar SP. 2009 - Enhanced decolorization and biodegradation of textile azo dye Scarlet $\mathrm{R}$ by using developed microbial consortium-GR. Bioresource Technology 100, 2493-2500.

Scott GM, Akhtar M, Swaney RE, Houtman CJ. 2002 - Recent developments in biopulping technology at Madison, Wisconsin. In: Viikari L and Lantto R (eds.). Progress in biotechnology. Biotechnology in the pulp and paper industry: 8th ICBPPI Meeting. Elsevier Amsterdam, 61-72. 
Wan C, Li Y. 2012 - Fungal pretreatment of lignocellulosic biomass. Biotechnology Advances 30, 1447-1457.

Wesenberg D, Kyriakides I, Agathos SN. 2003 - White-rot fungi and their enzymes for the treatment of industrial dye effluents. Biotechnology Advances 22, 161-187.

Wong JH, Ng TB, Cheung RCF, Ye XJ, Wang HX, Lam SK, Lin P, Chan YS, Fang EF, Ngai PHK, Xia LX, Ye XY, Jiang Y, Liu F. 2010 - Proteins with antifungal properties and other medicinal applications from plants and mushrooms. Applied Microbiology and Biotechnology 87, 1221-1235. 